\title{
Four images of projectification: an integrative review
}

\author{
Mattias Jacobsson \\ Umeå School of Business, Economics and Statistics, Umeå University, \\ Umeå, Sweden and \\ School of Engineering, Jönköping University, Jönköping, Sweden, and \\ Beata Jałocha \\ Faculty of Management and Social Communication, Jagiellonian University, \\ Kraków, Poland
}

Four images of projectification

\begin{abstract}
Purpose - The aim of this article is to give an overview of the development and current state of projectification research. The inquiry was driven by a threefold research question: How has projectification been understood and defined over time, what has the trajectory of the development been and what are the main trends and emerging ideas? Design/methodology/approach - The article is an integrative literature review of research done on the notion of projectification to date. An interdisciplinary, integrative literature review was conducted using Scopus and Web of Science as primary sources of data collection. The full data set consists of 123 journal articles, books, book chapters and conference contributions. With the data set complete, a thematic analysis was conducted.

Findings - Among other things, the review outlines the development and scope of projectification research from 1995 until 2021 and discusses four emerging images of projectification: projectification as a managerial approach, projectification as a societal trend, projectification as a human state and projectification as a philosophical issue. These characteristics emphasize some common features of each of the images but also imply that the way projectification is understood changes depending on the paradigmatic perspective taken by the researcher, the time and place in which the observation was made and the level of observation.

Originality/value - The authors have outlined and discussed four images of projectification - projectification as a managerial approach, projectification as a societal trend, projectification as a human state and projectification as a philosophical issue - where each image represents a special take on projectification with some prevalent characteristics. By doing this, the authors provide a systematic categorization of research to date and thus a basis upon which other researchers can build when furthering the understanding of projectification at large.
\end{abstract}

Keywords Project management, Project management research, Thematic analysis, Projectification, Literature review

Paper type Research paper

\section{Introduction}

The notion of projectification - broadly defined as the institutionalization of projects in society - is not new. About 25 years ago, Christophe Midler coined the term by providing a striking analysis of organizational projectification in his work on Renault, [1] published in a special issue of Scandinavian Journal of Management (Midler, 1995). In the article, Midler (1995) discussed contemporary industrial challenges of innovation-based competition and how the automotive industry and Renault responded to these challenges through an increase in project-based mode of operations. Throughout the years, the interest, level of analysis and

(C) Mattias Jacobsson and Beata Jałocha. Published by Emerald Publishing Limited. This article is published under the Creative Commons Attribution (CC BY 4.0) licence. Anyone may reproduce, distribute, translate and create derivative works of this article (for both commercial and non-commercial purposes), subject to full attribution to the original publication and authors. The full terms of this licence

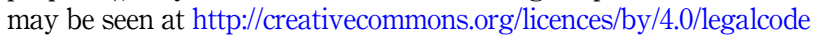

Beata Jałocha participated in this research as a result of the research project registered with no. 2016/ 23/D/HS4/01810, financed from the funds of the National Center for Science. 
IJMPB 14,7

1584

scope of research on projectification have increased, where studies today go beyond the projectification of industrial organisations and the Project management discipline where the interest originally started (Packendorff and Lindgren, 2014; Jensen et al., 2016). With this growing interest, scholars have acknowledged the drivers and consequences of projectification on other levels and areas of society. This has, for example, spurred more critical inquiries addressing the broader impact of projectification on individuals, nonprofit organizations and society at large ( $c f$. Boltanski and Chiapello, 2005; Hodgson and Cicmil, 2007; Lundin et al., 2015). A consequence of the increased interest and impact is also that the concept has been interpreted, reinterpreted and defined in different ways in the different scholarly fields it has been adopted by. Following this development, it has been argued that the notion of projectification deserves more attention. For example, Packendorff and Lindgren (2014, p. 7) argued that projectification "should be seen not only as a management fad and a structural trajectory in corporate restructuring, but also as a multifaceted phenomenon to be studied in its own right." To date, despite some recent conceptual contributions (see e.g. Maylor and Turkulainen, 2019), there are also no structured initiatives to bring together research on projectification from different scholarly fields. In the Guest Editorial of a recently published special section on projectification in International Journal of Managing Projects in Business, Schoper and Ingason (2019, p. 520) also call out for "more holistic" views on projectification. The present article builds on these observations, and in order to answer the recent calls, our aim is to give an overview of the development and current state of projectification research. By doing this, we provide a systematic categorization of research to date and thus a basis upon which other researchers can build when furthering the understanding of projectification at large. In order to reach this aim, an interdisciplinary, integrative literature review was conducted using Scopus and Web of Science (WoS) as primary sources of data collection. The full data set consists of 123 journal articles, books, book chapters and conference contributions (searches done up until 2021-06-17). The inquiry was driven by a threefold research question: How has projectification been understood and defined over time, what has the trajectory of the development been and what are the main trends and emerging ideas? Based on a systematic categorization and thematic analysis, we outline the development over time and present four emerging images of projectification: projectification as a managerial approach, projectification as a societal trend, projectification as a human state and projectification as a philosophical issue. These images reflect the development of research over time and are to be seen as parts, or perspectives, of the interdisciplinary understanding where projectification is today not to be understood as just one of these images, but all of them.

\section{Method}

Based on the increased interest, combined with the lack of previous comprehensive reviews of research on projectification, we decided to undertake an integrative literature review that provides the opportunity to "synthesize representative literature on a topic in an integrated way such that new frameworks and perspectives on the topic are generated" (Torraco, 2005, p. 356). The overall process follows the recommendations by Torraco (2005) and can be divided into three parts: (1) searching and retrieving data; (2) screening and structuring the material; and (3) coding, categorizing and analyzing the material, where conceptualization and presentation of results are included as the final part.

\subsection{Searching and retrieving data}

The data retrieval started by identifying appropriate selection criteria in terms of relevant inclusion and exclusion criteria. Based on the authors' familiarity with projectification research, and through presentations and feedback at workshops and two international 
conferences, the authors opted to use projectification as the search term in titles, abstracts or as a keyword (searches done in both Scopus and WoS). This was combined with searches for items that had cited the seminal article by Midler, from 1995 to the present day (searches done in Scopus). The reason for not searching for citations of Midler (1995) in WoS was that the Scandinavian Journal of Management (i.e. the journal where this seminal article was published) was not indexed in WoS at that time and thus not included. In parallel with identification of inclusion criteria, appropriate exclusion criteria were also developed; see Table 1 for a complete list.

When the search term was tested, full text searches were considered an option. However, tentative searches produced more than 4,000 hits, which was deemed unmanageable with the given integrative approach (Torraco, 2005), which involves reading and coding all identified items. Instead, we opted to allow for a snowball sample to be added to the primary data set. The rationale was to allow for the inclusion of items not indexed in $\mathrm{WoS}$ and Scopus, as well as items discussing the notion of projectification, but with a slightly different vocabulary, such as projectization and project intensification. Similar to projectification, these concepts aim at capturing the process of becoming projectified or increasing the use of projects in various ways, which is at the core of conceptualization.

Final searches in Scopus and WoS, were performed on the 17th of June 2021. A total of 613 items were identified in this process, $N=96$ in Scopus, $N=87$ in WoS and $N=298$ in Scopus (Midler citation). In addition, $N=132$ items were suggested through recommendations by scholars at international conferences and/or identified through searches in Google Scholar (i.e. through snowball sampling), giving a total of 613 items to include in the full data set. Out of the 132 items identified through the snowball sampling, 29 items were not accessible via any of the databases, open sources or other means available by the two authors. For example, some items suggested by scholars had been accepted for publication but were not available online, while other articles had been published in printed conference proceedings but not digitized. In order to be able to thoroughly assess these items, we decided to email the authors of the 29 items and ask for their assistance. All but two authors responded and were willing to assist. Items identified through this process were subjected to the same scrutiny and exclusion criteria in the screening process as all other identified items.

\subsection{Screening and structuring the material}

The screening process was conducted at two levels. The first level was based on title and abstract, and the second level was based on full texts. Before the authors started to assess the items, duplicates were identified and removed from the sample $(N=194)$, giving a total of 419 unique, and potentially relevant, items to assess. When applying the exclusion criteria to

Inclusion criteria

(1) Items have the term "projectification" in either the title, abstract or as a keyword (searches done in Scopus and Web of science)

(2) Items have cited Midler (1995) in Scopus

(3) Items have "projectification" in the title (searches conducted in Google Scholar) or have been recommended by peers
Four images of projectification

1585
Exclusion criteria

(1) Item is a duplicate

(2) Item is not available in English

(3) Items are not an academic text (journal articles, peer-review conference publications, academic thesis, books or book chapters written for academic purposes)

(4) Item is "non-topic": clearly has no connection to the phenomena of projectification (i.e., authors have not intentionally or actively used the concept of projectification as a key idea in their texts)
Table 1. Selection criteria 
IJMPB 14,7

\section{6}

abstracts, each item was first assessed individually by the two researchers and categorized into "included," "excluded" or "uncertain." If an item was categorized as uncertain, it was further assessed based on full text. After the individual assessments, the results were compared and discussed, resulting in 282 items to be removed and 137 unique items to be downloaded as full text. Five of the identified items were however subject to "forced exclusion," meaning that they were not available in any form. After downloading all items, full texts were read and nine additional items were removed due to them being assessed as "non-topic." All in all, giving a total of 123 items to be included in the review. For an overview of the screening process, see Figure 1.

2.2.1 Limitations related to the selection process. Based on the choices made in the selection process, the final data set is subject to limitations related to, for example, peer-review assessment, language and subject boundary, which requires some reflections. First, regarding the type of items included, it is common to limit searches to only include peerreviewed articles published in "renowned" journals, considered "certified knowledge" (Fernandez-Alles and Ramos-Rodríguez, 2009). As mentioned, when describing the sample selection, the sample includes a broader scope than mere publications in Scopus and WoS. The main rationale was to allow for the inclusion of items not indexed in WoS and Scopus, such as books, book chapters or $\mathrm{PhD}$ thesis. Consequently, a smaller number of the included items may not have been subjected to the same critical review and scrutiny as regular peerreviewed articles, but were instead critically assessed by the authors of this article. Out of the 124 items included in the full sample, 23 items are book chapters, 13 items are published in peer-reviewed conference proceedings and 4 items are books. We believe that broadening the scope allows us to engage in new or innovative ideas and approaches to projectification research, as well as more extensive engagement with the concept, which are frequently developed in a non-journal format. We made the assessment that the pros of a broadened sampling outweigh the cons.

Figure 1.

Flowchart of screening process

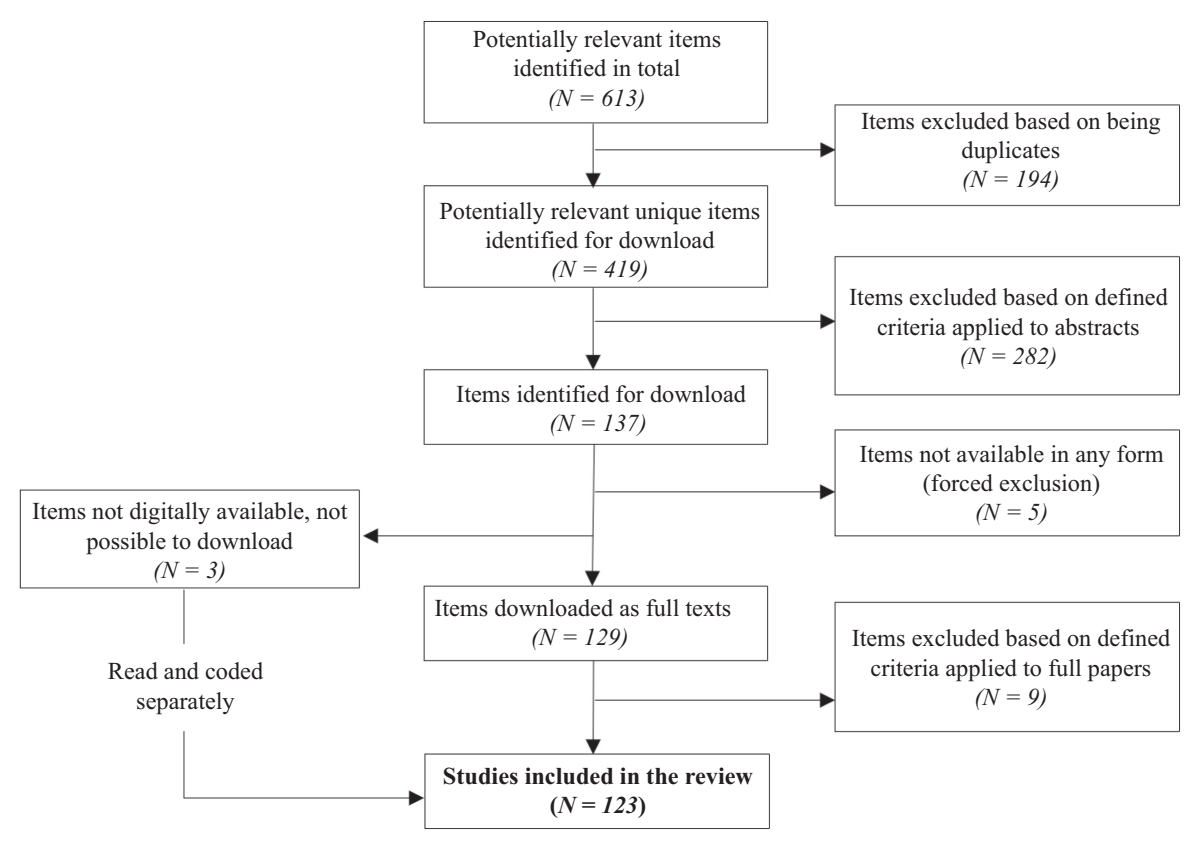


Second, we limited the review to only include items written in English. While this follows common practice, when conducting the searches, we came across a few contributions written in the two authors' native languages that could have been relevant to include in the review. Still, in order to avoid language bias, uphold coherence in sampling and given, for example, that the authors were not skilled enough in French to include Midler (1993), [2], it was concluded that the most appropriate decision was to exclude all non-English items.

Finally, regarding subject boundaries, with the review being focused on the concept of projectification, we had peer suggestions to include related concepts in the review such as temporary organisation(s), project-based organisations(s), programs and project portfolio. While we acknowledge the importance and relative closeness of these concepts as outcomes of a projectification process, the rationale for focusing solely on the notion of projectification relates to the fact that several previous reviews of the other abovementioned concepts already exist (see, e.g. Bakker, 2010; Burke and Morley, 2016; Miterev et al., 2017), as well as more conceptual articles attempting to clarify the boundaries of the various phenomena (see, e.g. Lundin and Söderholm, 1995; Packendorff, 1995; Modig, 2007; Jacobsson et al., 2015). From this review, however, it is clear that some scholars are key contributors to several of these concepts/areas. It should also be noted that despite the broadened sampling, there might still exist (nonidentified) research discussing similar ideas as projectification, but with a different vocabulary. However, through the iterative process of presenting and discussing earlier versions of the paper, as well as opening up for a snowball sampling with peer suggestions, we believe we have taken the necessary caution to minimize this risk. The review consequently covers contributions where authors consciously have used the concept of projectification in their research.

\subsection{Coding, categorizing and analyzing the material}

With the data set complete (consisting of 123 items), a thematic analysis and systematic categorization were conducted. Such a method enables a combination of flexibility and rigor (Braun and Clarke, 2006). Rigor is given by the structured stepwise procedure that provides a pathway from familiarizing with data to producing the final report (see Table 2). Flexibility is granted by the possibility to go beyond the explicit (or semantic) surface meanings and interpret the material on a latent level (Boyatzis, 1998; Braun and Clarke, 2006). A semantic coding implies coding for what is explicitly stated in the text, while a latent coding implies an attempt to go beyond the explicit and interpret underlying (nonexplicit) intentions or assumptions (Braun and Clarke, 2006). In the case of this review, semantic and latent codings were both required. Coding for explicit (semantic) surface meaning was important in order to outline, for example, the research context and how projectification had been defined in various studies, while the latent coding enables us to analyze and understand the various authors' interpretations and views of projectification, which was rarely explicitly mentioned

\begin{tabular}{|c|c|}
\hline \# Phases & Description of process \\
\hline (1) Familiarizing with data & Retrieving data, screening and structuring items \\
\hline (2) Generating initial codes & $\begin{array}{l}\text { Reading material, creating the codebook and coding the items using NVivo } \\
\text { Pro software. Systematically categorizing the items }\end{array}$ \\
\hline (3) Searching for themes & Continuous work concurrent with the coding process \\
\hline (4) Reviewing themes & Based on joint discussions when assessing the content of all codes \\
\hline $\begin{array}{l}\text { (5) Defining and naming } \\
\text { aggregate themes }\end{array}$ & $\begin{array}{l}\text { When an agreement was reached regarding content, naming was } \\
\text { descriptive and based on the aggregated content (that is, the four images) }\end{array}$ \\
\hline (6) Producing the report & Collaborative effort to present and discuss the results \\
\hline
\end{tabular}

Source(s): Adapted from Braun and Clarke (2006)

Table 2. Analytical process Four images of
projectification

1587

Source(s): Adapted from Braun and Clarke (2006) 
IJMPB

14,7

in the text. The analytical process can be described in six interrelated phases, as summarized in Table 2.

The first phase - familiarizing with data - overlapped with the process of searching, retrieving, screening and structuring the data set because of the need to read all abstracts and assess the content in order to apply the selection criteria (see Figure 1). The second phase generating initial codes - consisted of reading all full texts and coding the approximately 4,000 pages of material using NVivo Pro. This phase was undertaken jointly by the two researchers, working in parallel, with recurring reconciliation meetings. The researchers made preliminary notes while reading the material and creating codes, covering both a semantic and a latent level. The authors followed established principles; for example, keeping codes as precise and simple as possible. As the third phase - searching for themes - the coding was thoroughly discussed, resulting in a joint codebook, which was used in the final coding of all material. The codebook included 39 types of codes, aggregated into ten themes. Examples of themes are: areas of projectification, consequences of projectification, definitions used, levels of projectification, development of projectification, theoretical influences and emerging ideas. Apart from developing codes and themes, all items were also systematically categorized. The systematic categorization included information such as: date of publication, affiliation of authors on the date of publication, item type (journal article, book, book chapter, conference publication) and methodology used (quantitative, qualitative, mixed, N/A). Coding and systematic categorization were done in parallel and enabled the authors, as the fourth phase, to review themes and finally compare and contrast how the ten identified themes evolved over time and in relation to the various categories. For example, it enabled the authors to track how theoretical influences had altered, how levels of analysis had developed and how projectification had changed. This fourth phase consequently allowed for the identification of the trajectory of projectification research over time. Three different stages of projectification research and four different perspectives (later called images of projectification research) were identified in this process. These were reviewed and named in the fifth phase. The images were named projectification as a managerial approach, projectification as a societal trend, projectification as a human state and projectification as a philosophical issue and represents, among others, different ways in how projectification has been defined, different perceptions of the consequences of projectification, as well as different levels of analysis (for a summary, see Table 3). Finally, as phase 6 , the production of the report was a collaborative effort where it was decided to present the results in three parts following the identified results. Table 2 summarizes the phases of the analytical process.

\section{Twenty-five years of projectification research}

The results will, as mentioned above, be presented in three consecutive parts, moving from descriptive observations toward more analytical observations. First, we will provide an overview of the data set and provide some general observations regarding the various types of research done and approaches taken; we then outline the three stages and present the four identified images of projectification and finally discuss the significance and implication of these.

\subsection{An overview of the data and the development}

From the review it can be observed that there is a clear trend toward an increased scholarly interest in the concept of projectification. Although the aim of the study was not to discuss growth in any statistical terms, it is interesting to note that the research has increased from only occasional publications between 1995 and 2009, where the concept was discussed, to almost 100 between 2013 and 2021 (see Figure 2). 
Looking at Figure 2, it should be noted that the data is divided into three-year periods and that publications in 2021 do not cover the complete year. Although the last interval does not include three full years, there seems to be a continued growth of interest. Even if the concept of projectification was first coined in 1995, it is argued the underlying phenomenon dates back longer (Maylor et al., 2006). Peter (1992) might have been the earliest concretization when he talked about how future organizations would be "projectized," as all work would be done in project teams. Thus, the observed trend represents scholarly interest and not projectification as a phenomenon, although it is close at hand to assume that there is some sort of a correlation between change in practices in organizations and society and an increase in scholarly interest.

In terms of the different types of publications, journal articles are the most common type in the data set $(N=84)$, followed by book chapters $(N=16)$ and conference papers $(N=13)$. Academic theses and books account for ten items in total. Somewhat surprisingly, projectification research has been published in as many as 52 different journals. The most common publication outlets have been International Journal of Managing Projects in Business $(N=13)$ and International Journal of Project Management $(N=9)$. In terms of the author's country of affiliation when publications appeared, there is a clear overrepresentation of the Nordic countries (Norway, Sweden, Denmark and Finland). More than one-third of the included publications (45 out of 123) had solely Nordic authors, and 51 had only European authors (Nordic authors excluded). Nineteen publications were written in cross-country collaborations (where Nordic authors often are contributors), and only eight were written entirely by authors from outside Europe. The high representation of Nordic authors probably relates to the surge of the Scandinavian school of project management (Sahlin-Andersson and Söderholm, 2002; Kozarkiewicz et al., 2008; Jacobsson et al., 2016) and its subsequent impact on research interests and adoption of the projectification concept.

With regard to disciplines, there is, unsurprisingly, a high representation of contributions from the traditional Management and Project management disciplines. In total, more than one-third of the publications can be related to these two disciplines (and their related journals). Other clearly represented disciplines are Public policy, Political Science and Public management, as well as publications in disciplines such as Arts and Philosophy. In order to avoid a highly academic discussion concerning the demarcation between different disciplines and/or research areas, it can simply be concluded that the scope and variety of disciplines/ areas have grown over the years. An interesting observation is that if we limit the scope and only look at the period 2016-2021, there are more publications outside of the Management and Project management disciplines than within them.

In terms of research methodology, there is - as common with most novel research areas -a vast majority of both conceptual articles and case-based studies using various qualitative means of inquiry. To provide some examples of the variety, Baur et al. (2018) used interviews in their study of projectification of science; Fred and Hall (2017) had an ethnographically inspired case study approach in studying projectification in local governments; Bergman

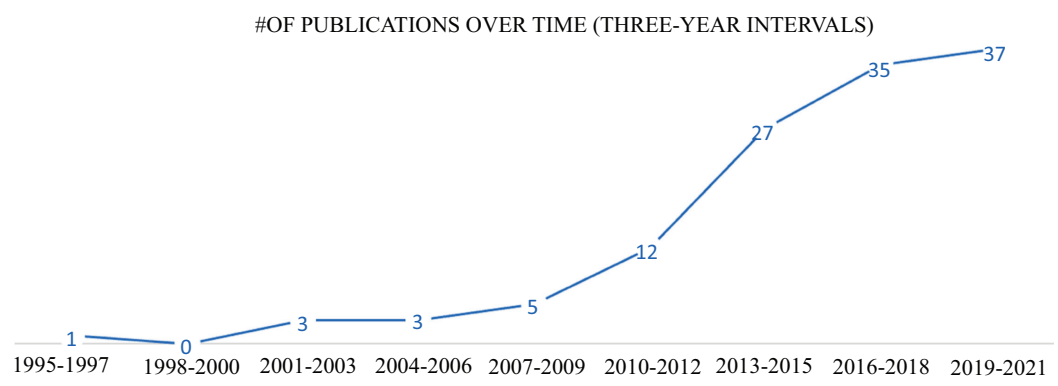

Figure 2. Graph of the publication development 
IJMPB 14,7

et al. (2013) combined narratives with retrospective company data to study change in a project-oriented organisation; Vermeulen (2015) combined document analysis and interviews; and Bredin and Söderlund (2006) based their study into projectification in R\&D-based companies on in-depth, semistructured interviews.

However, there are a couple of exceptions where projectification has been approached by quantitative means. The most notable examples are the attempts by Wald et al. (2015) and Müller et al. (2017) to develop a measurement for projectification. Müller et al. (2017) proposed that projectification on an organizational level should be measured along the dimensions of (a) the importance of PM in the organisation, (b) the existence of a PM career system, (c) project use as business principle in relations with customers, (d) the percentage of business based on projects and (e) a project mindset among the employees. Those authors argue that a higher level of these measures indicates higher levels of projectification. Wald et al. (2015), and later, Schoper et al. (2018) also try to quantify projectification on a national level. The latter constitutes a comparative study of Germany, Norway and Iceland, where projectification is quantified as the share of project work on total work. The article concludes that Germany is the most projectified of those three countries and that the "current degree of projectification in Western economies seems to be in a 30\% range" (Schoper et al., 2018, p. 80). Recently, Ingason et al. (2019) elaborate on these measurement attempts by conducting a comparative study of two different ways to measure projectification.

In contrast to research methodology, there is no clear trend when it comes to theoretical influences. Approximately half of the studies are rather "non-theoretical" in that they do not explicitly discuss theory or do not really engage in theory beyond the notion of projectification. However, there are a number of exceptions. Examples include studies that utilize the thinking of Foucault in their efforts (see, e.g. Jensen et al., 2016), studies that combine the ideas of Weick's loosely coupled system and institutional theory (see, e.g. Bergman et al., 2013) and studies that draw various conceptualizations of time to understand the consequences of projectification (see, e.g. Ylijoki, 2016; Dollinger, 2020). The most cohesive "exception" is the stream of critical theory studies on projectification (see, e.g. Cicmil et al., 2016; Lindgren and Packendorff, 2003, 2006; Waring and Thomas, 2010; Berglund et al., 2020).

\subsection{Four images of projectification research}

Beyond the more descriptive observations, four images of projectification research were identified through the review. These images have been conceptualized as:projectification as a managerial approach, projectification as a societal trend, projectification as a human state and projectification as a philosophical issue. Briefly, each image can be said to represent a special view (or perception) of what projectification is. The four identified images have emerged over time as a result of the broadened disciplinary interest and follow the identified trend of a growing number of publications, as well as the increase in the variety of theoretical, methodological and disciplinary contributions. Put another way, fresh eyes have added new perspectives and understandings over time. As illustrated in Figure 3, however, the four images should not be understood as merely relating to specific time periods, but rather as built up by representative fragments (or pixels), added along the way, which together form the basis for how projectification is understood today. Through each stage, the scope and number of pixels have grown, from projectification initially being acknowledged and studied solely as a structural trajectory in organizational restructuring, toward including studies of projectification more as a "cultural and discursive phenomenon," using the vocabulary of Packendorff and Lindgren (2014).

It should be pointed out that the numbers in Figure 3 represent those publications that are representative of a sole image. In the second and third stages, there's an increasing number of publications, which contribute to the understanding of more than only one image. In the second 


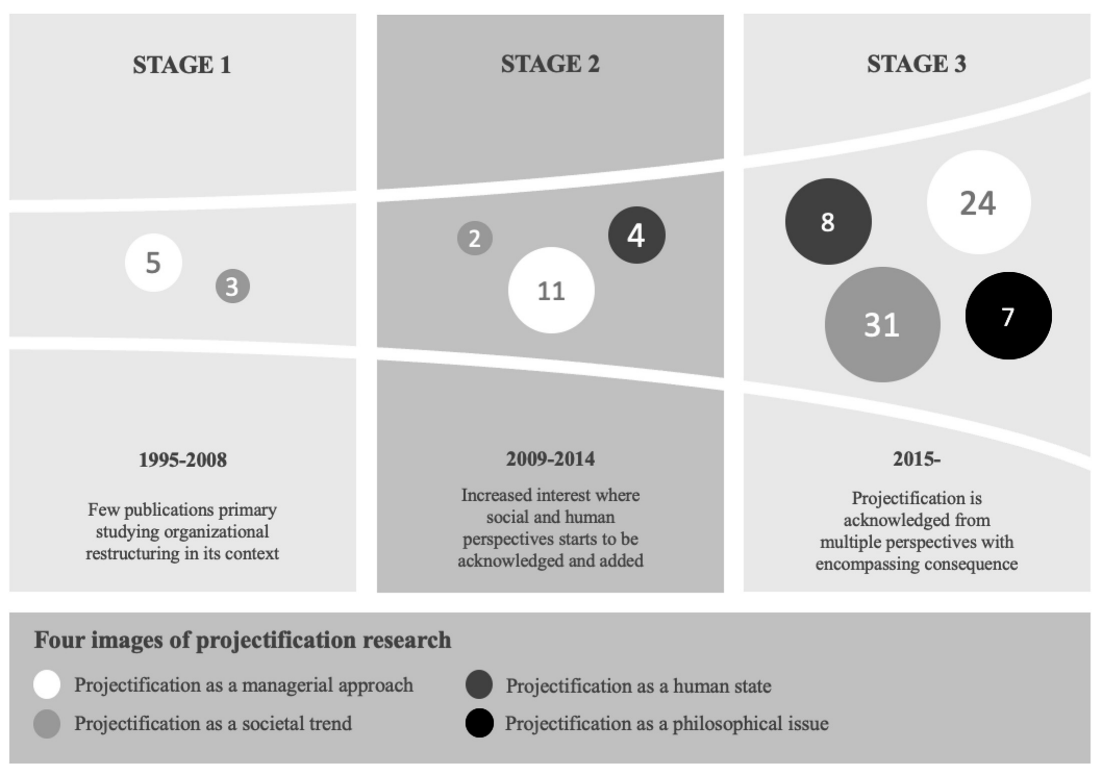

Four images of projectification

1591

Figure 3.

Four images of projectification evolving over time

stage, there are a total of 11 publications, and in the third stage, there are a total of 16 publications, which attempt to bring two or more images together. In the following sections, we will go further into each of the four images and provide examples of its contributing publications, or "pixels." In doing so, we will cover the level of analysis represented, common research areas, potential "gaps" and consequences observed and common definitions when given.

3.2.1 Projectification as a managerial approach. The first image, projectification as a managerial approach, originates in the first stage, starting in 1995. Projectification is seen here as an organizational restructuring initiative to increase the prevalence of projects in organisations, where, for example, the consequences on processes, organizational learning, governance structures and the institutionalization of project operations in industry have been of interest. At least initially, it has been argued that these changes were driven by changes in the global competitive climate. The common level of analysis is the meso-level, which is also the level at which projectification was first observed (Midler, 1995). Examples of research that provides pixels to this image are Midler (1995), Bredin (2006), Engwall and Jerbrant (2001), Bergman et al. (2013), Fred (2014), Wenell et al. (2017), Maylor and Turkulainen (2019) and Auschra et al. (2019).

We can note from the review that several clusters within this image, where there is a higher density of pixels, have developed over the years. This does not necessarily indicate that the projectification practices in these areas are the most intense or have some specifically unique features. This may simply be a consequence of researchers following already trodden paths or having easier access to specific contexts. Still, the identified clusters have a sectoral nature in the focus on public organisations, health service units, universities and research organisations, as well as non-governmental and business organisations. In the public sector, research concerns change in terms of how public organizations operate and deliver public services in the form of an increased number of projects as a response to New Public Management reforms (Abrahamsson and Agevall, 2010; Fred, 2018; Fred and Hall, 2017; Waring and Thomas, 2010). Similarly, in the case of higher education and healthcare, research focuses on the consequences of changing the organizational structures of universities (Fowler et al., 2015; Ylijoki, 2016; Baur et al., 2018; Dollinger, 2020) and 
IJMPB

14,7

medical units (Glasdam et al., 2015; Meinert and Whyte, 2014). Projectification is also subject to analysis in sectors with a high degree of project maturity, such as automotive and telecommunications (Bergman et al., 2013; Henning and Wald, 2019). Within this image, projectification is also studied as the pervasiveness of projects as the basic form of implementation of activities in the nongovernmental sector (Baker, 2014). A more recent research cluster is studies of projectification of/in transnational and global organisations (see, e.g. Büttner and Leopold, 2016; Godenhjelm et al., 2015; Jałocha et al., 2019).

With regard to the level of analysis, the organizational or meso-level is the focal point. Arvidsson (2009), for example, stated that in projectified organizational structures, the specific challenges are tensions related to managerial action of various kinds. Bredin and Söderlund (2006) analyzed the implications of project intensification on the HRM practice of the firms. Midler (2019) presented the importance of the organization's projectification characteristics as an important vector for successfully implementing the firms' internationalization strategies. Maylor and Turkulainen (2019) provided illustrations and a warning concerning the assumptions that are made as an organization advance in its projectification. Successively, Wald et al. (2015) noted that projectification leads to a change in the predominant logic of coordination and control.

When it comes to consequences of projectification within this image, some studies (e.g. Bogacz-Wojtanowska and Jałocha, 2016; Henning and Wald, 2019) have underlined the negative impact on organizations (e.g. in some sectors increasing projectification reduces innovativeness, which may lead to fewer jobs or decrease in income, projectification invites also excessive bureaucracy in organizations). However, these are in the minority and usually also consider the positive effects, while critically evaluating them. Definitions of projectification vary, but clearly adhere to the notion that projectification is a matter of organizational restructuring initiatives toward organizing by projects. Although Midler (1995) is almost always cited, it contains no precise definition of projectification. At the same time, the whole study can be seen as a way to define projectification in terms of how it analyzes a process of organizational transformation (Aubry and Lenfle, 2012). Bredin and Söderlund (2011) also provided a descriptive definition when interpreting Midler's (1995) work. They wrote: "Projectification [according to Midler, can be defined as] a change of the organizational structure, slowly moving the firm into putting more emphasis on the project dimension of the organizational structure, from strong functional units where projects have played a subordinate role, to projects playing at center stage with functional units acting as labor pools" (Bredin and Söderlund, 2011, p. 9). Similarly, Maylor et al. (2006) defined projectification as "a change in organizational and governance structure to increase the primacy of the processes of projects within a central organization and its supply networks"; Kuura (2011, p. 118) defined it as "a general development process in which firms to a greater extent focus their operations on projects, project management, and various types of project-like structures"; and Bredin and Söderlund (2011, p. 9) as "a move from repetitive production to nonroutine work processes and the use of temporary projects". Most of the definitions of projectification, up until 2012, follow the same pattern of making the organization the focal point. The prevailing focus on organizations has previously been acknowledged and also criticized. For example, Packendorff and Lindgren (2014, p. 10) termed the interest in organizational projectification "a narrow view" on projectification.

Thus, research that contributes to this image has focused mainly on inter-organizational predicaments and has left intraorganizational issues related to projectification aside. Questions such as how projectification might influence the processes of cooperation, collaboration and coopetition among organizations would benefit from further investigation, as would questions related to redistribution of power. For example, how might projectified organizations stimulate (or force) projectification processes in other organizations?

3.2.2 Projectification as a societal trend. In the second image, projectification as a societal trend, projectification is acknowledged as a long-term result of the embeddedness of project 
practices in social structures. The analysis is centered on the macro-level and indicates an interest in the outcomes and consequences of projectification on parts of the society or on society at large. At its core, this image is still tightly linked to the micro- and meso-level changes of organizing by projects, but takes a much broader scope than the first image on impact and consequences.

Studies within this image have also studied projectification in a wide variety of contexts. Examples include the role of projectification when it comes to ways to combat epidemics (Glasdam et al., 2015; Meinert and Whyte, 2014), projectification of public policies (Bailey and Hodgson, 2019; Jensen et al., 2017; Mukhtar-Landgren and Fred, 2019; Ojehag-Pettersson, 2017), the projectified method of distributing funds for research (Baur et al., 2018; Fowler et al., 2015; Brajdić Vuković et al., 2020) and international aid (Baker, 2014; Hubmann, 2021). However, there are also new and emerging research areas in which the causes and effects of projectification processes are considered, such as ecology (Hodge and Adams, 2016), entrepreneurship (Auschra et al., 2019) and sustainable development (Cerne and Jansson, 2019; Ćwikła et al., 2020). This broader view on projectification allows for an understanding of both the complexity of the phenomenon and its consequences for the development of society at large. Descriptions of the effects of projectification on social structures can be found in the literature that discusses changes to the way work is performed. Projectification is seen here as part of a larger trend transforming society and the way people live and work on a global scale. The work of Boltanski and Chiapello (2005) seems to be particularly important and inspiring for the understanding of social changes influenced by projectification. The authors pointed out how the project form of organizing corresponds to the great neoliberal changes taking place on a global scale, when the world is viewed as a network. Boltanski and Chiapello (2005) stated that the "new spirit of capitalism" is based on the assumptions of the projective city, so projectification changes global social structures, not only organizations or individuals.

The consequences of projectification on a societal or macro-level, which is what this image reflects, were analyzed in a comprehensive way by Jensen (2012) and Lundin et al. (2015) based on the idea of a project society and the criticality of projects for strategic development in our societies. Others, such as Žarković et al. (2014), have also suggested that society will have to accept that certain projects may cause a different distribution of capital and changes in the current power hierarchy. Meinert and Whyte (2014) and Whyte et al. (2013) noted that a projectified way of responding to epidemics such as AIDS may have far-reaching social consequences related to, inter alia, the temporariness of project activities. In turn, Szántó (2016), referring to the attempts to remedy society after a devastating war in Sierra Leone, one of the poorest countries in the world, drew attention to the omnipresence of short-term projects. According to Szántó (2016), the project society, resulting from the projectification of aid activities, causes difficulties in the process of real improvement of the situation in the country.

Within this image, projectification is primarily "defined" by giving descriptions. For example, Karrbom Gustavsson and Hallin (2015, p. 5) described projectification as "a response to larger societal and cultural processes that are habitual, legitimate and performative". Packendorff and Lindgren (2014) argued for taking a "broad view" and to theorize projectification as a cultural and discursive phenomenon, and by that, moving the attention from only organizational processes and structures toward consequences for individuals, industrial networks and society. Other authors have followed the suggestion of Packendorff and Lindgren (2014) to take a broad view. One such example is Kalff (2017, p. 18), who argued that projectification "describes a tendency whereby individual life, as well as the economic activity of firms and organizations, is subjected to ongoing transformations". Munck af Rosenschöld (2019, p. 335) might have provided the clearest attempt to define what such a view entails when he stated that projectification can be conceptualized as " $a$ process or development toward greater social, cultural, and political importance of projects."

Four images of projectification 
IJMPB

14,7

There are several openings to further research within this image. Following some of the previous contributors, inquiries into what drives projectification on a macro-level would benefit from further investigation. For example, what influences the projectification of whole countries and regions and how; and how can the relationship between projectification and globalization be understood? Or the role of measurability and accountability for, or in, this development. Moreover, questions related to societal changes might also benefit from further investigation. For example, what are the implications for public policies implementation on the macro-scale, when public policies become projectified, and what social changes does the process of societal projectification induce?

3.2.3 Projectification as a human state. The third identified image, projectification as a human state, is built on ideas that reflect micro-level projectification. Researchers contributing to this image of projectification show an interest in the consequences of projectification on humans, such as changes in work relations and/or private life due to increased participation in project work. In essence, the micro-level is centered on the role and identity of the individual, in the project (or projectified) organizations and society. Research adding pixels to this image often refers to projectification in terms of personal or individual projectification, or discusses the actions of the individuals involved in project-based work. Some examples of research that have engaged is such type of research are Ekstedt (2009), Jensen (2012), Packendorff and Lindgren (2014), Cicmil et al. (2016), Jensen, et al. (2016, 2017), Kalff (2017), Ballesteros-Sánchez et al. (2019), Lunkka et al. (2019) and Berglund et al.(2020).

The main unit of analysis is naturally the individual or a small group (including professional groups, such as scientists or artists), experiencing struggles and difficulties associated with being part of the projectified world. Projectification as a human state implies a departure from the repetitive action to work on unique projects, the need to be in constant communication with stakeholders and the willingness to work extra hours, in matrix structures, often sacrificing work-life balance. Regardless of the industry or geographic location of the studied individuals, they experience quite similar, most often negative, effects of projectification. Thus, researchers tend to focus on the negative impact of projectification, rather than its potential positive effects. The negative consequences of projectification in relation to disadvantaged or vulnerable groups, such as patients, immigrants or precarious workers, are particularly highlighted. Consequently, the image of projectification as a human state stands in stark contrast to the acknowledged consequences in the image of projectification as a managerial approach (e.g. Henning and Wald (2019), who show the positive impact of projectification on companies and other organizations).

In the image of projectification as a human state, we can also notice theoretical inspirations that have their source beyond mainstream project management and management theory, especially in psychology. Considerations about the well-being of individuals involved in projects and the consequences of these activities draw attention to the psychological and health aspects of project work. As research suggests, one factor that contributes to negative individual projectification is the technocratization of organizing. In projectified organizations, individuals become immersed in the process and lose their ability to challenge it or engage in a debate over their situation (Waring and Tomas, 2010). Cicmil et al. (2016) suggested that project discourses may have more far-reaching existential consequences for project workers. According to the mentioned authors, projectification "can create conditions that are hard to cope with, hard to justify, hard to control-despite the grand promise of project management to deliver the reasonable, the rational and the controllable" (Cicmil et al., 2016 p. 59). On the other hand, Waring and Tomas (2010) stated that "micro emancipation" from projectification is still possible, where emancipation refers to the process through which individuals free themselves from oppressive conditions.

As mentioned, the literature contributing to this image has devoted a lot of attention to the negative consequences on individuals. Ekstedt (2009) wrote that, as a result of this trend, the risk 
(e.g. in relation to the revenues gained) may be transferred from companies to the individuals. Kalff (2017) noted that project management regulates individual labour efforts. The (negative) consequences of projectification for scientists (e.g. Ylijoki, 2016; Baur et al., 2018), teachers (Dollinger, 2020), artists (Szreder, 2015), as well as workers in general (Packendorff and Lindgren, 2014; Cicmil et al., 2016) are also highlighted and discussed. Analyzing the impact of projects directed at emigrants, Abrahamsson and Agevall (2010, pp. 204-205) described the "disappointment and frustration among the project participants", who experience "feelings of powerlessness". Baur et al. (2018) noted that the time frameworks within which research projects are implemented make it difficult to follow the unexpected research results and research becomes more output-oriented. Cicmil et al. (2016, p. 59) suggested that "project discourses may have more far-reaching existential consequences for project workers", and furthermore that projectification of work life may contribute to people declining in their senses of progress, hope and personal worthiness. Based on their research conducted in Norway, Myrmæl and Alfredsen (2018, p. 131) indicated that project workers experience "sleeping difficulties and are subject to negative mental stress". Exploring other "dark sides of projectification," Bråthen and Ommundsen (2018) have studied the connection between project work exposure and employees' well-being. Other authors further refer to the negative consequences of projectification, such as inequality, career insecurity and unemployment (e.g. Brunila, 2011; Sage, 2016).

When it comes to definitions, this image also suffers from a lack of distinctiveness. Researchers often provide descriptions but rarely definitions, suggesting that projectification is related to, for example, the adaptation of professional project tools to private life, but also to a more general way of being a part of the project society. However, Jensen et al. (2016) suggested that there should be a new way of understanding projects and their role in society where projects are acknowledged as a human condition. Cicmil et al. (2016, p. 59) suggested that projectification is "a complex ethical problem with consequences for long-term sustainability of organizations and society and it may expose workers, individually and collectively, to vulnerable situations". They argued that exposure to projectification processes leads individuals to, inter alia, "dependence on great expectations, follies and sensations; commitment to blank sheets, fresh starts and 'professional' performance, internalisation of honour/shame and personal worthiness, exhaustion, finiteness and the end of resilience" (Cicmil et al., 2016, p. 61).

Despite the many important pixels that have been recently added to this image, many relevant micro-level inquiries remain to further pursue. Interestingly, the potential positive effects of projectification on individuals have been overlooked, and the gender or social dimensions of projectification have generally not been covered. It would be relevant to explore questions such as how projectification affects the social situations of women and men and how (or if) projectification leads to the greater professional emancipation of women. Furthermore, issues related to projectification and lifelong learning are also largely uncovered. For example, how might projectification impact lifelong learning processes of individuals when projects are used as the main method of learning at all levels of education and how might individuals' competence development and learning be affected by increased projectification?

3.2.4 Projectification as a philosophical issue. In the fourth and final image, projectification as a philosophical issue, projectification is seen as a metaphysical shift in the perception of time, space and work, where the project semantics have become so pervasive that it, unreflected upon and often unnoticed, creeps into our daily vocabulary, our culture and our everyday lives. Referring to Pierre Bourdieu's concept of habitus (Bourdieu, 1977), projectification imperceptibly becomes a kind of meta-habitus. Reflecting this image, in a project society a social group is born whose common background is not social class, religion or nationality, but the project. Individuals are being socialized to project culture and projects become anchored in the body or daily practices of individuals, groups, societies and nations. Examples of works within this image are Jensen (2012), Packendorff and Lindgren (2014), Jensen et al. (2016) and Barondeau and Hobbs (2019).
Four images of projectification 
IJMPB

14,7

In the image of projectification as a philosophical issue, researchers have made the first attempts to define the ontological foundations of projectification by showing how certain properties of a projectified reality translate into the nature of social reality. Thus, projectification is fundamentally a socially changing phenomenon with complex consequences. The emergent challenges of projectification, which have so far been understood primarily from a strictly technical, organizational or social perspective, are captured using a philosophical apparatus. Jensen (2012) noted that the task-based method of implementing project work is no longer just an organizational form, but also determines the ways of shaping cooperation and social relations. Jensen stated that, in the project society, basic variables (space, time, acting and connectivity) have changed and affect not only organizations but, most of all, human life. To outline the ontological assumptions of projectification, Jensen (2012, p. 126) used the concepts of disciplinary and project society, arguing that "the twentieth century witnessed how the project society was slowly leaking out from the chinks of the disciplinary society."

Jensen developed this idea further with Thuesen and Geraldi in a work on projectification of everything, where projects are understood as human condition (Jensen et al., 2016). In an attempt to define the project society and its ontological foundations, the authors drew the distinction between disciplinary and project societies, noting that in a disciplinary society, forms of activity such as work and personal life were undertaken in specific places in space. In a project society, because projects can be implemented anywhere, the boundaries between what is individual and what is collective, private and public, work and free time, are constantly violated. Packendorff and Lindgren (2014, p. 13), making a cross-sectional analysis of the consequences of projectification, also paid attention to the following emerging areas, which may be analyzed from the philosophical point of view: "(re-)masculinisation of post-bureaucratic work practices [...] the performative notion of project management as creeping into established professional identities [.. . ] construction of new power relations in the wake of standardisation and professional certification initiatives". Others have discussed the changes in the perception and conceptualization of time, which is perceived as limited, allocated, measurable and often equated to numerical values, described as a projectified timescape (e.g. Dollinger, 2020; Ylijoki, 2016).

At the meta-level, where this image is slowly emerging, projectification has a rather negative connotation. Some researchers have underlined that the reality of the projectified world seems to be a dangerous dystopia, a materialized nightmare of projectification of everything (Skórzyńska, 2018). Following in the footsteps of these initial attempts to understand projectification from a philosophical standpoint, there still seems to be plenty of room for further inquiry of what projectification is, what its boundaries are and how it is to be understood at large. For example, with projectification being acknowledged as a process of institutionalization and change on various levels, what is the outcome beyond the observed consequences? Who benefits from projectification? And how does projectification influence our timescape in the long term?

\subsection{Toward a multilevel conceptualization of projectification}

As outlined, each of the four above-presented images constitutes an important and prevalent perspective on the current state of projectification research. Combined, the images also constitute a synthesis along the line with the purpose of an integrative literature review (Torraco, 2005) and thus a new framework to build on when developing projectification research in the future.

The four images reflect the diversity in scholarly backgrounds and various contributions to date. In the summary table (Table 3), we highlight and juxtapose some of the core characteristics of each image in terms of prevalent view, main level of analysis and perceived value and acknowledged consequences. 


\begin{tabular}{|c|c|c|c|c|}
\hline Images & $\begin{array}{l}\text { Prevalent view on } \\
\text { projectification }\end{array}$ & $\begin{array}{l}\text { Main level } \\
\text { of analysis }\end{array}$ & Inherent value and consequences & $\begin{array}{l}\text { Four images of } \\
\text { projectification }\end{array}$ \\
\hline $\begin{array}{l}\text { Projectification as a } \\
\text { managerial approach }\end{array}$ & $\begin{array}{l}\text { An organizational restructuring } \\
\text { initiative to increase the } \\
\text { prevalence of projects in } \\
\text { organizations }\end{array}$ & Meso & $\begin{array}{l}\text { Projectification is acknowledged as } \\
\text { mainly a positive phenomenon, and } \\
\text { enables adaptability and collective } \\
\text { learning }\end{array}$ & \\
\hline \multirow{2}{*}{$\begin{array}{l}\text { Projectification as a } \\
\text { societal trend }\end{array}$} & \multirow{2}{*}{$\begin{array}{l}\text { The long-term result of the } \\
\text { embeddedness of project } \\
\text { practices in culture and societal } \\
\text { structures }\end{array}$} & \multirow[t]{2}{*}{ Macro } & \multirow{2}{*}{$\begin{array}{l}\text { Projectification is an unavoidable } \\
\text { trend with both negative and } \\
\text { positive consequences }\end{array}$} & 1597 \\
\hline & & & & \\
\hline $\begin{array}{l}\text { Projectification as a } \\
\text { human state }\end{array}$ & $\begin{array}{l}\text { The implications of the } \\
\text { reinforcement of the project } \\
\text { discourse on humans }\end{array}$ & $\begin{array}{l}\text { Micro- } \\
\text { Macro }\end{array}$ & $\begin{array}{l}\text { Projectification is largely described } \\
\text { as an oppressive discourse with } \\
\text { far-reaching negative } \\
\text { consequences for project workers }\end{array}$ & \\
\hline $\begin{array}{l}\text { Projectification as a } \\
\text { philosophical issue }\end{array}$ & $\begin{array}{l}\text { A metaphysical shift in the } \\
\text { perception of time, space and } \\
\text { work }\end{array}$ & $\begin{array}{l}\text { Macro and } \\
\text { Meta }\end{array}$ & $\begin{array}{l}\text { Projectification is described as a } \\
\text { fundamentally socially changing } \\
\text { phenomenon with complex } \\
\text { consequences }\end{array}$ & $\begin{array}{r}\text { Table } 3 . \\
\text { Characteristics of the } \\
\text { four images of } \\
\text { projectification }\end{array}$ \\
\hline
\end{tabular}

Moving toward a multilevel interpretation, the four images can be seen metaphorically as a spatial sculpture where the understanding and interpretation of what projectification is and what its consequences are change depending on the perspective and level of analysis taken. An example of such a spatial sculpture is the statue of Swietowit, which, according to west Slavic mythology, is a four-headed god of fertility and war. His four heads, each looking in a separate direction, symbolize the four directions of the compass and thus the ability to take a broader perspective.

Similar to the symbolism of Świetowit, this review intends to provide a broad take on projectification research through the four images. The notion behind such an approach is that projectification today is not just one of these images, but all of them. Each image represents one direction, or part of contemporary understanding, the complexity and existing views of projectification. Holistically, as a spatial sculpture and with all the four images considered simultaneously, projectification can be defined as the institutionalization of projects in society, in terms of the process where projects become embedded within all levels and areas of society through belief, norms, values, structures and modes of behavior. As shown through the review, this institutionalization process is penetrating our present world and also influences how we perceive it. In comparison to earlier works that have provided important contributions to the understanding of projectification, this paper adds another piece to the puzzle. The presented four images of projectification, for example, develop the idea of narrow and broad conceptualizations (Packendorff and Lindgren, 2014), it adds to the discussion on organizational projectification in its context (Maylor and Turkulainen, 2019) and can be seen as a direct response to the call for multilevel perspectives on projectification (Schoper and Ingason, 2019).

\section{Conclusions}

The starting point for this review was to give an overview of the development and current state of projectification research. In the introduction we asked: How has projectification been understood and defined over time, what has been the trajectory of the development and what are the main trends and emerging ideas? 
IJMPB

14,7

It can be concluded from the initial part of the review that research on projectification has grown steadily over the last 25 years. This growth manifests itself in different ways. It has led to an increased variety of research areas, inquiries moving from being purely qualitative toward including quantitative means, an emerging interest in the use of theory and a broadening of disciplinary interests. An important observation in this regard is that more publications are now produced outside of the traditional Management and Project management disciplines than within. Additionally, we can conclude that the level of analysis has grown from a case where projectification was solely acknowledged as a structural trajectory in organizational restructuring, toward viewing projectification as a fundamentally socially changing phenomenon with complex consequences. Unsurprisingly, it can be observed how definitions of projectification have followed a similar trajectory. Finally, we can conclude that there is a very high representation of Nordic authors and a striking lack of studies from outside Europe. However, we would claim that this observation is more a reflection of researchers' interests, schools of thought and ability to access data than a reflection of where and how the phenomenon of projectification has developed.

Beyond these descriptive observations, we have outlined and discussed four images of projectification - projectification as a managerial approach, projectification as a societal trend, projectification as a human state and projectification as a philosophical issue - where each image represents a special take on projectification with some prevalent characteristics. These characteristics emphasize some common features of each of the images, but also imply that the way projectification is understood changes depending on the paradigmatic perspective taken by the researcher, the time and place in which the observation was made and the level of observation. As highlighted when outlining this conceptualization, projectification as a phenomenon is characterized by a kind of fluidity and amorphism; the phenomenon has no clear boundaries and "cascades" throughout society with varying consequences, both good and bad (Jałocha, 2019). It is clear that researchers over the years have learned more and more about projectification and adopted more variated research approaches. However, the spatial "sculpture" of projectification remains somewhat blurry and would benefit from further attention.

\subsection{Roads forward}

Enriching (or clarifying) the notion of projectification can be done in at least three different ways. The first is by adding more "pixels" (i.e. publications) to each image, thereby providing higher resolution, more color and depth. Second, by bridging or connecting the images to create a more encompassing and coherent "sculpture" (i.e. covering more than one level of research). Third, by developing and adding totally new images in terms of perspectives and approaches. From the review, we find that all three roads forward are feasible.

The first is in terms of increasing the resolution by adding missing "pixels." Adding pixels, or filling gaps, is a common way to move research forward, even if it should be noted that not all gaps necessarily have to be filled (Billsberry, 2013). Readers will note how, with each image, we have identified a number of "gaps" and suggestions for future research. Rather than repeating all of those here, we will mention a few in general.

It became clear in the review that research is skewed toward qualitative inquiries. Studying projectification from either a mixed-methods approach or further the initial attempts to quantify projectification (see, e.g. Schoper et al., 2018; Wald et al., 2015; Ingason et al., 2019) has clear potentials. Quantitative means would make it possible to further the discussion on projectification development, degree of projectification and projectification maturity (see, e.g. Müller et al., 2016; Skeibrok and Svensson, 2016). It is also possible to increase the resolution by exploring and deepening research that has just started. As mentioned, there is little research 
from an emancipatory-, feminist- or postcolonial perspective that could help explain the complexity and multidimensionality of the phenomena.

The second road forward involves bridging and connecting the images. In this respect, interdisciplinary studies, drawing from several of the represented areas, could clearly be a way forward. Combinations of various research disciplines might enable researchers to understand how projectification spreads between different parts of society and the consequences thereof. Moreover, such an approach would open up for multinational research, including comparative studies of projectification between industries and/or nations. This would preferably include non-European countries, given the relative lack of such studies.

The reviewed literature is full of novel ideas and concepts. Among the new ideas discussed, a few could be of particular relevance to explore further. These concepts include "agents of projectification" (Fred, 2018), "deprojectification" (Lundin, 2012), "over-projectification" (Lundin, 2016), "Post-Project Society" (Lundin, 2016), "project class" (Kovách and Kučerova, 2006), "projectification of everything" (Jensen et al., 2016), "projectified self" (Kalff, 2017), "projectariat" (Baker, 2014), "vulnerability and resistance" (Cicmil et al., 2016) and "projects as human condition" (Jensen et al., 2016). Most of these are not easily mapped to one specific image; instead, they already serve as small bridges between the images or constitute embryos of such bridges. Particularly novel are some of the concepts that address projectification on the metalevel (e.g. "projects as human condition," "projectification of everything" and "overprojectification"). As mentioned, the omnipresence of projectification and its impact on people and society also prompt reflection on the ethical consequences. Research into ethics in the context of entanglement in the project society seems to be very much needed.

The third road refers to adding totally new images, of which there might be several. From the review there are also some indications of an additional image related to, for example, the long-term consequences of projectification and the (or a) idea of a world that is (or becoming) too projectified and/or becoming less projectified. Some of the emerging ideas seem to represent counter reactions to projectification as it is understood today; see, for example, the notions of "deprojectification" (Lundin, 2012) and "post-project society" (Lundin, 2016). What we might see in these ideas is an embryo of yet another image of (de)projectification as a trend, or counterreaction, where projectification is understood as a phenomenon that comes and goes based on other macro processes and movements such as globalization and geopolitical changes.

On a final note, it is clear that the seminal paper by Midler, published over 25 years ago, is a cornerstone in the project literature. From the review, however, it is clear that the legacy has reached far beyond this. As illustrated by the four images, the notion of projectification has over the years inspired and been adopted by researchers who represent many other scientific disciplines, where the concept clearly has contributed with new colors and insights.

\section{Notes}

1. The results were first published in 1993, but only in French, in the book "L'auto qui n'existait pas" (Midler, 1993; Aubry and Lenfle, 2012).

2. The French book "L'auto qui n'existait pas," constitutes the basis for the seminal paper.

\section{References}

Abrahamsson, A. and Agevall, L. (2010), "Immigrants caught in the crossfire of projectification of the Swedish public sector: short-term solutions to long-term problems", Diversity and Equality in Health and Care, Vol. 7 No. 3, pp. 201-209.

Arvidsson, N. (2009), "Exploring tensions in projectified matrix organisations", Scandinavian Journal of Management, Vol. 25 No. 1, pp. 97-107.

Aubry, M. and Lenfle, S. (2012), "Projectification: Midler's footprint in the project management field", International Journal of Managing Projects in Business, Vol. 5 No. 4, pp. 680-694. 
IJMPB 14,7

Auschra, C., Braun, T., Schmidt, T. and Sydow, J. (2019), "Patterns of project-based organizing in new venture creation: projectification of an entrepreneurial ecosystem", International Journal of Managing Projects in Business, Vol. 12 No. 1, pp. 48-70.

Bailey, S. and Hodgson, D. (2019), "Pilots as projects. Policy making in a state of exception", in Hodgson, D., Fred, M., Bailey, S. and Hall, P. (Eds), The Projectification of the Public Sector, Routledge, New York, pp. 130-148.

Baker, C. (2014), "The local workforce of international intervention in the yugoslav successor states: 'precariat' or 'projectariat'? Towards an agenda for future research", International Peacekeeping, Vol. 21 No. 1, pp. 91-106.

Bakker, R.M. (2010), "Taking stock of temporary organizational forms: a systematic review and research Agenda”, International Journal of Management Reviews, Vol. 12 No. 4, pp. 466-486.

Ballesteros-Sánchez, L., Ortiz-Marcos, I. and Rodríguez-Rivero, R. (2019), "The project managers' challenges in a projectification environment", International Journal of Managing Projects in Business, Vol. 12 No. 3, pp. 522-544.

Barondeau, R. and Hobbs, B. (2019), "A pragmatic sociological examination of projectification", International Journal of Managing Projects in Business, Vol. 12 No. 2, pp. 282-297.

Baur, N., Besio, C. and Norkus, M. (2018), "Projectification of science as an organizational innovation”, in Rammert, W., Windeler, A., Knoblauch, H. and Hutter, M. (Eds), Innovation Society Today, Springer VS, Wiesbaden, pp. 341-370.

Berglund, K., Lindgren, M. and Packendorff, J. (2020), "The worthy human being as prosuming subject: 'Projectified Selves' in emancipatory project studies", Project Management Journal, Vol. 51 No. 4, pp. 367-377.

Bergman, I., Gunnarson, S. and Räisänen, C. (2013), "Decoupling and standardization in the projectification of a company", International Journal of Managing Projects in Business, Vol. 6 No. 1, pp. 106-128.

Billsberry, J. (2013), “A longitudinal empirical study into the buildup of fluff in my belly button”, Journal of Management Education, Vol. 37 No. 5, pp. 595-600.

Bogacz-Wojtanowska, E. and Jałocha, B. (2016), "The bright side of social economy sector's projectification: a study of successful social enterprises", Project Management Research and Practice, Vol. 3, pp. 1-20.

Boltanski, L. and Chiapello, E. (2005), "The new spirit of capitalism”, International Journal of Politics, Culture, and Society, Vol. 18 Nos 3-4, pp. 161-188.

Bourdieu, P. (1977), Outline of a Theory of Practice, Vol. 16, Cambridge University Press, Cambridge.

Boyatzis, R.E. (1998), Transforming Qualitative Information: Thematic Analysis and Code Development, Sage, USA.

Bråthen, C. and Ommundsen, M. (2018), The "Dark Side" of Projectification: The Impact of Project Work on the Employees' Well-Being. A Quantitative Study of the Impact of Project Work Exposure on Employees' Work-Related Well-Being, University of Adger, Norway.

Brajdić Vuković, M., Vignjević Korotaj, B. and Ćulum Ilić, B. (2020), "STEM colonization: applying hard sciences' socio-organisational patterns and evaluation procedures to the soft sciences in Croatia”, European Journal of Education, Vol. 55 No. 4, pp. 542-559.

Braun, V. and Clarke, V. (2006), "Using thematic analysis in psychology", Qualitative Research in Psychology, Vol. 3 No. 2, pp. 77-101.

Bredin, K. (2006), "Human resource management in project-based organisations: challenges and changes", Licentiate Thesis at the Department of Management and Economics, Linköping University, Sweden.

Bredin, K. and Söderlund, J. (2006), "Perspectives on human resource management: an explorative study of the consequences of projectification in four firms", International Journal of Human Resources Development and Management, Vol. 6 No. 1, pp. 92-113.

Bredin, K. and Söderlund, J. (2011), "Projectification on the way", in Bredin, K. and Söderlund, J. (Eds), Human Resource Management in Project-Based Organizations, Palgrave Macmillan, London, pp. 1-22. 
Brunila, K. (2011), "The projectisation, marketisation and therapisation of education", European Educational Research Journal, Vol. 10 No. 3, pp. 421-432.

Burke, C.M. and Morley, M.J. (2016), "On temporary organizations: a review, synthesis and research agenda”, Human Relations, Vol. 69 No. 6, pp. 1235-1258.

Büttner, S. and Leopold, L. (2016), "A 'new spirit' of public policy? The project world of EU funding", European Journal of Cultural and Political Sociology, Vol. 3 No. 1, pp. 41-71.

Cerne, A. and Jansson, J. (2019), "Projectification of sustainable development: implications from a critical review", International Journal of Managing Projects in Business, Vol. 12 No. 2, pp. 356-376.

Cicmil, S., Lindgren, M. and Packendorff, J. (2016), "The project (management) discourse and its consequences: on vulnerability and unsustainability in project-based work", New Technology, Work and Employment, Vol. 31 No. 1, pp. 58-76.

Ćwikła, M., Góral, A., Bogacz-Wojtanowska, E. and Dudkiewicz, M. (2020), "Project-based work and sustainable development - a comparative case study of cultural animation projects", Sustainability, Vol. 12 No. 16, p. 6519.

Dollinger, M. (2020), “The projectification of the university: consequences and alternatives", Teaching in Higher Education, Vol. 25 No. 6, pp. 669-682.

Ekstedt, E. (2009), "A New Division of Labour: the "projectification" of working and industrial life", in Moreau, M.-A., Negrelli, S. and Pochet, P. (Eds), Building Anticipation of Restructuring in Europe, P.I.E-Peter Lang S.A, Bern, pp. 31-53.

Engwall, M. and Jerbrant, A. (2001), "Exploring the multi-project matrix: process dynamics of a projectified organization", The 61st Annual meeting of the Academy of Management, Washington, DC, August 3-8, 2001.

Fernandez-Alles, M. and Ramos-Rodríguez, A. (2009), "Intellectual structure of human resources management research: a bibliometric analysis of the journal Human Resource Management, 1985-2005”, Journal of the American Society for Information Science and Technology, Vol. 60 No. 1, pp. 161-175.

Fowler, N., Lindahl, M. and Sköld, D. (2015), “The projectification of university research: a study of resistance and accommodation of project management tools \& techniques", International Journal of Managing Projects in Business, Vol. 8 No. 1, pp. 9-32.

Fred, M. (2014), "Porous organizing. Making sense of projectification in Swedish municipalities", the 7th Making Project Critical workshop, Stockholm: KTH Royal Institute of Technology.

Fred, M. (2018), Projectification: The Trojan Horse of Local Government. Doctoral Thesis at the Faculty of Social Sciences, Lund University, Sweden.

Fred, M. and Hall, P. (2017), "A projectified public administration how projects in Swedish local governments become instruments for political and managerial concerns", Statsvetenskaplig Tidskrift, Vol. 119 No. 1, pp. 185-205.

Glasdam, S., Oeye, C. and Thrysoee, L. (2015), "Patients' participation in decision-making in the medical field - 'projectification' of patients in a neoliberal framed healthcare system", Nursing Philosophy, Vol. 16 No. 4, pp. 226-238.

Godenhjelm, S., Lundin, R.A. and Sjöblom, S. (2015), "Projectification in the public sector - the case of the European Union”, International Journal of Managing Projects in Business, Vol. 8 No. 2, pp. 324-348.

Henning, C.H.C.A. and Wald, A. (2019), "Toward a wiser projectification: macroeconomic effects of firmlevel project work", International Journal of Project Management, Vol. 37 No. 6, pp. 807-819.

Hodge, I. and Adams, W.M. (2016), "Short-term projects versus adaptive governance: conflicting demands in the management of ecological restoration", Land, Vol. 5 No. 4, pp. 1-17.

Hodgson, D. and Cicmil, S. (2007), "The politics of standards in modern management: making "the project' a reality", Journal of Management Studies, Vol. 44 No. 3, pp. 431-450. 
IJMPB 14,7

Hubmann, M. (2021), "Chronicity of disruptive project rhythms: the projectification of the "post-Ebola" health system rebuilding in Sierra Leone", Time and Society, Vol. 30 No. 3, pp. 379-401, doi: 10. 1177/0961463X211005207.

Ingason, H.T., Fridgeirsson, T.V. and Jonasson, H.I. (2019), "Projectification in Iceland measured-a comparison of two methods", International Journal of Managing Projects in Business, Vol. 12 No. 3, pp. 602-616.

Jacobsson, M., Lundin, R.A. and Söderholm, A. (2015), "Researching projects and theorizing families of temporary organizations", Project Management Journal, Vol. 46 No. 5, pp. 9-18.

Jacobsson, M., Lundin, R.A. and Söderholm, A. (2016), "Towards a multi-perspective research program on projects and temporary organizations: analyzing the Scandinavian turn and the rethinking effort”, International Journal of Managing Projects in Business, Vol. 9 No. 4, pp. 752-766.

Jałocha, B., Góral, A. and Bogacz-Wojtanowska, E. (2019), "Projectification of a global organization case study of the Roman Catholic Church", International Journal of Managing Projects in Business, Vol. 12 No. 2, pp. 298-324.

Jałocha, B. (2019), “The European Union's multi-level impact on member state projectification in light of neoinstitutional theory", International Journal of Managing Projects in Business, Vol. 12 No. 3, pp. 578-601.

Jensen, A.F. (2012), The Project Society, Aarhus Universitetsforlag, Denmark.

Jensen, A., Thuesen, C. and Geraldi, J. (2016), "The projectification of everything: projects as a human condition”, Project Management Journal, Vol. 47 No. 3, pp. 21-34.

Jensen, C., Johansson, S. and Löfström, M. (2017), "Projectification of the Public Human Servicesidentifying four 'archetypical' project organizations based on time, space and relationship challenges", International Research Society for Public Management (IRSPM) 21th Annual Conference in Budapest, Budapest, April 19-21, 2017, pp. 1-26.

Kalff, Y. (2017), "The knowledge worker and the projectified self: domesticating and disciplining creativity", Work Organisation, Labour and Globalisation, Vol. 11 No. 1, pp. 10-27.

Karrbom Gustavsson, T. and Hallin, A. (2015), "Project overflow and the projectification of societytaking a step back", EGOS, Athens, June 9-11, 2015.

Kovách, I. and Kučerová, E. (2006), "The project class in Central Europe: the Czech and Hungarian cases", Sociologia Ruralis, Vol. 46 No. 1, pp. 3-21.

Kozarkiewicz, A., Łada, M. and Söderholm, A. (2008), "Scandinavian school of project management research: theory oriented towards practice", Organizacja I Kierowanie, Vol. 1, pp. 23-38.

Kuura, A. (2011), "Policies for projectification: support, avoid or let it be?", Estonian Discussions on Economic Policy, Vol. 19 No. 1, pp. 117-136.

Lindgren, M. and Packendorff, J. (2003), "Deconstructing projects: towards critical perspectives on project theory and projecticised society", Making Projects Critical: A Crisis of Instrumental Rationality?, Bristol Business School, Bristol, UK. University of the West of England, April 1011, 2003, pp. 1-26.

Lindgren, M. and Packendorff, J. (2006), "Projects and prisons", in Hodgson, D. and Cicmil, S. (Eds), Making Projects Critical, Palgrave, London, pp. 111-131.

Lundin, R.A. (2012), "Projectification and deprojectification: learning and developing strategy in TV production companies", IFSAM Congress 2012, University of Limerick, Ireland, June 2629, pp. 1-4.

Lundin, R.A. (2016), "Project society: paths and challenges", Project Management Journal, Vol. 47 No. 4, pp. 7-15.

Lundin, R.A. and Söderholm, A. (1995), “A theory of the temporary organization”, Scandinavian Journal of Management, Vol. 11 No. 4, pp. 437-455.

Lundin, R.A., Arvidsson, N., Brady, T., Ekstedt, E., Midler, C. and Sydow, J. (2015), Managing and Working in Project Society, Cambridge University Press, Cambridge. 
Lunkka, N., Pietiläinen, V. and Suhonen, M. (2019), "A discursive sensemaking perspective on projectbased work in public healthcare”, Project Management Journal, Vol. 50 No. 6, pp. 657-672.

Maylor, H. and Turkulainen, V. (2019), "The concept of organisational projectification: past, present and beyond?", International Journal of Managing Projects in Business, Vol. 12 No. 3, pp. 565-577.

Maylor, H., Brady, T., Cooke-Davies, T. and Hodgson, D. (2006), "From projectification to programmification”, International Journal of Project Management, Vol. 24 No. 8, pp. 663-674.

Meinert, L. and Whyte, S.R. (2014), "Epidemic projectification: AIDS responses in Uganda as event and process", The Cambridge Journal of Anthropology, Vol. 32 No. 1, pp. 77-94.

Midler, C. (1993), L'auto qui n'existait pas. Management des projets et transformation de l'entreprise, InterEditions, Paris.

Midler, C. (1995), "Projectification" of the firm: the Renault case", Scandinavian Journal of Management, Vol. 11 No. 4, pp. 363-375.

Midler, C. (2019), "Projectification: the forgotten variable in the internationalization of firms' innovation processes?", International Journal of Managing Projects in Business, Vol. 12 No. 3, pp. 545-564.

Miterev, M., Turner, J.R. and Mancini, M. (2017), "The organization design perspective on the projectbased organization: a structured review", International Journal of Managing Projects in Business, Vol. 10 No. 3, pp. 527-549.

Modig, N. (2007), "A continuum of organizations formed to carry out projects: temporary and stationary organization forms", International Journal of Project Management, Vol. 25 No. 8, pp. 807-814.

Mukhtar-Landgren, D. and Fred, M. (2019), "Re-compartmentalizing local policies? The translation and mediation of European structural funds in Sweden", Critical Policy Studies, Vol. 13 No. 4, pp. 488-506.

Müller, R., Zhai, L., Wang, A. and Shao, J. (2016), "A framework for governance of projects: governmentality, governance structure and projectification”, International Journal of Project Management, Vol. 34 No. 6, pp. 957-969.

Müller, R., Zhai, L. and Wang, A. (2017), "Governance and governmentality in projects: profiles and relationships with success", International Journal of Project Management, Vol. 35 No. 3, pp. 378-392.

Munck af Rosenschöld, J. (2019), "Inducing institutional change through projects? Three models of projectified governance", Journal of Environmental Policy and Planning, Vol. 21 No. 4, pp. 333-344.

Myrmæl, I.E. and Alfredsen, H.H. (2018), The "Dark Side" of Projectification: The Impact of Project Work on the Employees' Emotions. What Are the Negative Aspects of Project Work and its Effects on the Individual Project Worker's Emotions in a Project Life Cycle?, University of Agder, Norway.

Öjehag-Pettersson, A. (2017), "Working for change: projectified politics and gender equality", NORA Nordic Journal of Feminist and Gender Research, Vol. 25 No. 3, pp. 163-178.

Packendorff, J. (1995), "Inquiring into the temporary organization: new directions for project management research", Scandinavian Journal of Management, Vol. 11 No. 4, pp. 319-333.

Packendorff, J. and Lindgren, M. (2014), "Projectification and its consequences: narrow and broad conceptualisations", South African Journal of Economic and Management Sciences, Vol. 17 No. 1, pp. 7-21.

Peters, T. (1992), Liberation Management: Necessary Disorganization for the Nanosecond Nineties, Alfred A, New York.

Sage, D. (2016), "Professionalization, projectification and pressurization: insights from construction project management", in Wilkinson, A., Hislop, D. and Coupland, C. (Eds), Perspectives on Contemporary Professional Work: Challenges and Experiences, Edward Elgar Publishing, UK, USA, pp. 338-361. 
IJMPB 14,7

Sahlin-Andersson, K. and Söderholm, A. (2002), Beyond Project Management: New Perspectives on the Temporary-Permanent Dilemma, Liber, Malmö.

Schoper, Y. and Ingason, H.T. (2019), "Projectification and the impact on societies", International Journal of Managing Projects in Business, Vol. 12 No. 3, pp. 517-521.

Schoper, Y.G., Wald, A., Ingason, H.T. and Fridgeirsson, T.V. (2018), "Projectification in Western economies: a comparative study of Germany, Norway and Iceland", International Journal of Project Management, Vol. 36 No. 1, pp. 71-82.

Skeibrok, J. and Svensson, F.L. (2016), The Degree of Projectification in Organizations, and its Impact on Strategic Flexibility: A Quantitative Study of the Norwegian Economy, University of Agder, Norway.

Skórzyńska, A. (2018), "We make up the rules as we go along? Projektyzacja, 'bystre' miasta i widma emergencji”, Zarzadzanie W Kulturze, Vol. 19 No. 3, pp. 233-256.

Szántó, D. (2016), "Reading project society in the landscape: Sierra Leone, 2018-2012", Acta Ethnographica Hungarica, Vol. 61 No. 1, pp. 227-241.

Szreder, K. (2015), "How to radicalize a mouse? Notes on radical opportunism", in Dockx, N. and Gielen, P. (Eds), Mobile Autonomy. Exercises in Artists' Self-Organization, Valiz, Amsterdam, pp. 183-205.

Torraco, R.J. (2005), "Writing integrative literature reviews: guidelines and examples", Human Resource Development Review, Vol. 4 No. 3, pp. 356-367.

Vermeulen, N. (2015), "From virus to vaccine: projectification of science in the VIRGO consortium", in Penders, B., Vermeulen, N. and Parker, J.N. (Eds), Collaboration across Health Research and Medical Care: Healthy Collaboration, Ashgate Publishing, Surrey, pp. 31-58.

Wald, A., Schneider, C., Spanuth, T. and Schoper, Y. (2015), "Towards a measurement of "projectification": a study on the share of project-work in the German economy", in Wald, A., Wagner, R., Schneider, C. and Gschwendtner, M. (Eds), Advanced Project Management: Flexibility and Innovative Capacity, GPM, Nürnberg, Vol. 4, pp. 1-22.

Waring, T. and Thomas, P. (2010), "The insidious growth of societal projectification: emancipatory research with public sector staff in the North of England", 5th Making Projects Critical Workshop, Bristol, UK, 20-22 January 2010.

Wenell, T., Ekstedt, E. and Lundin, A. (2017), "'On the road to project society - a Swedish story: managing and working in project society", PM World Journal, Vol. 6 No. 1, pp. 1-6.

Whyte, S.R., Whyte, M., Meinert, L. and Twebaze, J. (2013), "Therapeutic clientship: belonging in Uganda's projectified landscape of AIDS care", in Biehl, J. and Petryna, A. (Eds), When People Come First, Princeton University Press, Princeton, pp. 140-165.

Ylijoki, O.H. (2016), "Projectification and conflicting temporalities in academic knowledge production", Teorie vědy/Theory of Science, Vol. 38 No. 1, pp. 7-26.

Žarković, N., Vrečko, I. and Barilović, Z. (2014), "Creating holistic project-knowledge society through project management education in research and development", Procedia-Social and Behavioral Sciences, Vol. 119, pp. 210-218.

\section{Corresponding author}

Beata Jałocha can be contacted at: beata.jalocha@uj.edu.pl

For instructions on how to order reprints of this article, please visit our website:

www.emeraldgrouppublishing.com/licensing/reprints.htm

Or contact us for further details: permissions@emeraldinsight.com 